\title{
ANALISIS PENILAIAN KESEHATAN PT. ASURANSI JIWASRAYA (PERSERO) DITINJAU DARI ASPEK KEUANGAN BERDASARKAN PERMEN BUMN NOMOR : PER-10/MBU/2014
}

\author{
Mahaitin H Sinaga ${ }^{1}$, Liharman Saragih ${ }^{2}$, Wico J Tarigan ${ }^{3}$ \\ Universitas Simalungun ${ }^{123}$
}

\section{N F O A R T I K E L \\ Riwayat Artikel: \\ Received : May, 17 th 2021 \\ Revised : June, $9^{\text {th }} 2021$ \\ Accepted : June $11^{\text {th }} 2021$}

\section{Keywords:}

Keywords: Health Level, Financial Aspect, Permen BUMN No: PER$10 / M B U / 2014$

\section{Kata Kunci:}

Tingkat Kesehatan, Aspek Keuangan, Permen BUMN Nomor: PER-10/MBU/2014

\begin{abstract}
A B S T R A C T
This study aims to see the financial condition of PT. Asuransi Jiwasraya (Persero) which has an impact on the company's failure to pay claims to customers in 2020. The research approach used is a quantitative approach. Analysis of the assessment of the level of financial soundness using the Permen BUMN No: PER-10/MBU/2014. The data collection technique uses a study of documentation sourced from the Annual Financial Report of PT. Asuransi Jiwasraya (Persero) for the period 2015-2020. The results showed that: (1) PT. Asuransi Jiwasraya (Persero) has experienced financial problems since 2018. (2) ROA, liquidity, and RBC aspects show that since 2018, the financial position of PT. Asuransi Jiwasraya (Persero) is in the "Very Poor" criteria. (3) since 2018, the health level of PT. Asuransi Jiwasraya (Persero) is already in the worst position, namely "Unhealthy with a C predicate".
\end{abstract}

\section{A B S T R A K}

Penelitian ini bertujuan untuk melihat kondisi keuangan PT. Asuransi Jiwasraya (Persero) yang berdampak atas kegagalan perusahaan ini membayar klaim terhadap nasabah pada tahun 2020. Pendekatan penelitian yang digunakan adalah pendekatan kuantitatif. Analisis penilaian tingkat kesehatan keuangan menggunakan Peraturan Menteri BUMN Nomor: PER10/MBU/2014. Teknik pengumpulan data menggunakan studi dokumentasi yang bersumber dari Laporan Keuangan Tahunan PT. Asuransi Jiwasraya (Persero) periode 2015-2020. Hasil penelitian menunjukkan bahwa: (1) PT. Asuransi Jiwasraya (Persero) telah mengalami permasalahan keuangan sejak tahun 2018. (2) aspek ROA, likuiditas, dan RBC menunjukkan bahwa sejak tahun 2018, posisi keuangan PT. Asuransi Jiwasraya (Persero) adalah berada pada kriteria "Sangat Kurang". (3) sejak tahun 2018, tingkat kesehatan PT. Asuransi Jiwasraya (Persero) sudah berada pada posisi terburuk yaitu "Tidak Sehat dengan predikat C". 


\section{PENDAHULUAN}

Kasus gagal bayarnya PT. Asuransi Jiwasraya (Persero) yang diungkap oleh BPK RI di awal tahun 2020 dimana perusahaan tidak mampu membayar klaim polis yang jatuh tempo khususnya produk JS Saving Plan. Kasus ini menjadi polemik yang sangat menghebohkan di masyarakat sehingga mengakibatkan menurunnya tingkat kepercayaan masyarakat khususnya di bidang jasa perasuransian. Dan tidak tanggung-tanggung, jumlah kerugian yang harus ditanggung oleh negara adalah sebesar Rp 13,7 triliun, suatu angka yang sangat fantastis. Skema penyelamatan dan restrukturisasi juga sudah dilakukan oleh banyak pihak termasuk pemerintah di dalamnya yang harus ikut terlibat untuk menyelamatkan perusahaan jasa perasuransian dimaksud. Permasalahan gagal bayar ini tentu saja tidak terjadi dalam waktu yang singkat. Bisa saja dikarenakaan telah mengalami permasalahan beberapa tahun sebelumnya. Demikian juga dengan yang dialami oleh PT. Asuransi Jiwasraya (Persero),bisa saja permasalahan gagal bayar ini telah terjadi beberapa tahun sebelumnya sebelum BPK RI mengangkat permasalahan ini di awal tahun 2020.

Dalam pengawasannya terhadap perusahaan - perusahaan milik negara, Pemerintah RI melalui Kementerian BUMN sebenarnya telah memiliki suatu acuan untuk melakukan pengawasan dengan melakukan penilaian terhadap kinerja atau pun penilaian kesehatan untuk semua perusahaan-perusahaan milik negara. Acuan dimaksud telah tertuang dalam Keputusan Menteri Negara Badan Usaha Milik Negara Nomor KEP-100/MBU/2002 tentang pedoman Penilaian Tingkat Kesehatan BUMN yang berlaku bagi seluruh BUMN Non Jasa Keuangan maupun BUMN Jasa Keuangan kecuali Persero Terbuka dan BUMN yang dibentuk dengan Undang - undang tersendiri.

Khusus bagi perusahaan-perusahaan milik negara yang bergerak di bidang jasa keuangan, Kementerian BUMN pun telah memiliki suatu standar penilaian kesehatan dengan diterbitkannya Peraturan Menteri Negara Badan Usaha Milik NegaraNomor : PER - 04/MBU/2011Tentang Indikator Penilaian Tingkat Kesehatan Badan Usaha Milik Negara Jasa Keuangan Bidang Usaha Perasuransian dan Jasa Penjaminan. Kemudian untuk menyesuaikan beberapa indikator pada peraturan di atas, Kementerian BUMN kemudian menyempuranakannya dengan menerbitkan Peraturan Menteri Negara Badan Usaha Milik Negara PER-10/MBU/2014

Rumusan Masalah

Berdasarkan latar belakang masalah yang telah diuraikan di atas maka dapat dirumuskan masalah yang dikaji dalam penelitian ini adalah "Bagaimana tingkat kesehatan PT Asuransi Jiwasraya (Persero) ditinjau dari aspek keuangan berdasarkan Peraturan Menteri Negara Badan Usaha Milik Negara Nomor :PER-10/MBU/2014 sehingga mengalami gagal bayar di tahun 2020 .

\section{KAJIAN PUSTAKA}

\section{Pengertian dan Bentuk Badan Usaha Milik Negara}

Dalam (Undang-undang no 19, 2003) tentang Badan Usaha Milik Negara disebutkan bahwa Badan Usaha Milik Negara merupakan salah satu pelaku kegiatan ekonomi dalam perekonomian nasional berdasarkan demokrasi ekonomi.Menurut KEP-100/MBU/2002, bentuk badan usaha BUMN dikelompokkan dalam 2 kelompok yaitu BUMN Non Jasa Keuangan dan BUMN Jasa Keuangan kecuali Persero Terbuka dan BUMN yang dibentuk dengan Undang - undang tersendiri. BUMN non jasa keuangan adalah BUMN yang bergerak di bidang infrastruktur dan non infrastruktur dan BUMN jasa keuangan adalah BUMN yang bergerak dalam bidang usaha perbankan, asuransi, jasa pembiayaan dan jasa penjaminan. 


\section{Penilaian Tingkat Kesehatan BUMN Jasa Keuangan Bidang Usaha Perasuransian dan Jasa Penjaminan}

Seiring dengan kebutuhan yang lebih spesifik dalam hal penilaian tingkat kesehatan perusahaan pada perusahaan - perusahaan yang bergerak di bidang usaha jasa keuangan, maka Kementerian BUMN menetapkan Peraturan Menteri Negara Badan Usaha Milik Negara Nomor : PER-04/MBU/2011 tentang Indikator Penilaian Tingkat Kesehatan BUMN Jasa Keuangan Bidang Usaha Perasuransian dan Jasa Penjaminan. Terakhir kali, dikarenakan adanya beberapa rumus yang harus disesuaikan, maka Indikator Penilaian Tingkat Kesehatan BUMN Jasa Keuangan Bidang Usaha Perasuransian dan Jasa Penjaminan Permen ini diubah menjadi PER-10/MBU/2014.

Dalam Permen BUMN Nomor PER-10/MBU/2014 ini, tingkat kesehatan ditetapkan berdasarkan penilaian kinerja untuk tahun buku yang bersangkutan meliputi penilaian Aspek Keuangan, Aspek Operasional, dan Aspek Administrasi dan dibedakan untuk delapan perusahaan asuransi yang berstatus BUMN. PT Asuransi Jiwasraya (Persero) merupakan salah satu dari delapan perusahaan yang dimaksud. Berdasarkan Permen BUMN Nomor PER-10/MBU/2014 di atas, Indikator dan Bobot Penilaian untuk aspek keuangan untuk PT Asuransi Jiwasraya (Persero) disajikan pada Tabel 1 di bawah :

\begin{tabular}{|c|c|c|}
\hline \multicolumn{3}{|c|}{ Tabel 1. Indikator dan Bobot Penilaian } \\
\hline No. & Indikator & Bobot \\
\hline $\mathbf{A}$ & Aspek Keuangan & \\
\hline \multirow[t]{3}{*}{1.} & Rentabilitas & \\
\hline & a. $\mathrm{ROE}$ & 7.5 \\
\hline & b. ROA & 7.5 \\
\hline 2. & RBC / Solvabilitas & 10 \\
\hline \multirow[t]{2}{*}{3.} & Likuiditas & 10 \\
\hline & Total & 35 \\
\hline B & Aspek Operasional & \\
\hline 1. & RKI & 10 \\
\hline 2. & YOI & 10 \\
\hline 3. & Pertumbuhan Premi/Iuran/IJP & 10 \\
\hline 4. & Underwriting Yield & 10 \\
\hline \multirow[t]{2}{*}{5.} & Expense Ratio & 10 \\
\hline & Total & 50 \\
\hline C & Aspek Administratif & \\
\hline 1. & Laporan Perhitungan Tahunan & 3 \\
\hline \multirow{2}{*}{$\begin{array}{l}2 . \\
3 .\end{array}$} & Rancangan RKAP & 3 \\
\hline & Laporan Periodik & 3 \\
\hline \multirow[t]{5}{*}{4.} & Kinerja PKBL & \\
\hline & a. Efektivitas Penyaluran & 3 \\
\hline & b. Tingkat Kolektibilitas & 3 \\
\hline & Total & 15 \\
\hline & Total Bobot & 27 \\
\hline \multicolumn{2}{|c|}{$\begin{array}{l}\text { Sumber: Permen BUMN No. PER- } \\
10 / \mathrm{MBU} / 2014\end{array}$} & \\
\hline
\end{tabular}

Pada Tabel 1 di atas terlihat bahwa total bobot penilaian untuk aspek keuangan adalah 35, untuk aspek operasional adalah 50, dan untuk aspek administrasi adalah 15 atau total bobot keseluruhan adalah berjumlah 100 .

Untuk menentukan status baik tidaknya tingkat kesehatan keuangan perusahaan, di bawah disajikan suatu daftar skor untuk menentukan skor dari masing - masing hasil penghitungan setiap indikator PT. Asuransi Jiwasraya (Persero). Total skor dari masing - 
masing indikator inilah yang dijumlahkan untuk mendapatkan bobot dari ketiga aspek keuangan, aspek operasional dan aspek administratif. Daftar Skor untuk Aspek Keuangan PT. Asuransi Jiwasraya (Persero) tersaji pada Tabel 2 di bawah ini :

Tabel 2. Daftar Skor Aspek Keuangan PT. Asuransi Jiwasraya (Persero)

\begin{tabular}{ccccccccc}
\hline \multicolumn{2}{c}{ 1. Return on Equity } & \multicolumn{2}{c}{ 2. Return on Assets } & \multicolumn{2}{c}{ 3. Likuiditas } & \multicolumn{2}{c}{ 4. Risk Based Capital } & \multirow{2}{*}{ Kriteria } \\
ROE (\%) & Score & ROA (\%) & Score & \% & Score & RBC (\%) & Score & \\
\hline $\mathrm{ROE} \geq \mathrm{x}+4$ & 7,5 & $\mathrm{ROA} \geq 5$ & 7,5 & $\mathrm{x} \geq 150$ & 10 & $\mathrm{x} \geq 150$ & 10 & Sangat Baik \\
$\mathrm{x}+4>\mathrm{ROE} \geq \mathrm{x}+3$ & 6 & $5>\mathrm{ROA} \geq 4$ & 6 & $150>\mathrm{x} \geq 130$ & 8 & $150>\mathrm{x} \geq 130$ & 8 & Baik \\
$\mathrm{x}+3>\mathrm{ROE} \geq \mathrm{x}+2$ & 4,5 & $4>\mathrm{ROA} \geq 3$ & 4,5 & $130>\mathrm{x} \geq 120$ & 6 & $130>\mathrm{x} \geq 120$ & 6 & Cukup \\
$\mathrm{x}+2>\mathrm{ROE} \geq 0$ & 2 & $3>\mathrm{ROA} \geq 0$ & 2 & $120>\mathrm{x} \geq 100$ & 3 & $120>\mathrm{x} \geq 100$ & 3 & Kurang \\
$\mathrm{ROE}<0$ & 0 & $\mathrm{ROA}<0$ & 0 & $\mathrm{x}<100$ & 0 & $\mathrm{x}<100$ & 0 & Sangat Kurang \\
\hline
\end{tabular}

Catatan: $\mathrm{x}=$ BI Rate

Sumber: Permen BUMN Nomor PER-10/MBU/2014

Dengan adanya Tabel Skor di atas, maka hasil penghitungan Return on Equity, Return on Asets, Likuiditas, dan Risk Based Capital dapat memperlihatkan apakah setiap indikator di atas memiliki kriteria Sangat Baik, Baik, Cukup, Kurang, dan Sangat Kurang.Namun untuk melakukan penilaian apakah perusahaan-perusahaan milik negara ini sehat atau tidak,dapat ditentukan berdasarkan Tabel 3 di bawah ini :

\begin{tabular}{|c|c|c|}
\hline \multicolumn{2}{|r|}{ KRITERIA } & \multirow[t]{2}{*}{ TOTAL SKOR (TS) } \\
\hline a & Sehat & \\
\hline & AAA & $>95$ \\
\hline & AA & $80<\mathrm{TS} \leq 95$ \\
\hline & A & $65<\mathrm{TS} \leq 80$ \\
\hline \multicolumn{3}{|c|}{ b $\quad$ Kurang Sehat } \\
\hline & BBB & $50<\mathrm{TS} \leq 65$ \\
\hline & BB & $40<\mathrm{TS} \leq 50$ \\
\hline & в & $30<\mathrm{TS} \leq 40$ \\
\hline \multicolumn{3}{|c|}{ c $\quad$ Tidak Sehat } \\
\hline & $\mathrm{CCC}$ & $20<\mathrm{TS} \leq 30$ \\
\hline & $\mathrm{CC}$ & $10<\mathrm{TS} \leq 20$ \\
\hline & $\mathrm{C}$ & $\mathrm{TS} \leq 10$ \\
\hline
\end{tabular}

Total Skor (TS) yang dimaksud dalam tabel di atas adalah total skor hasil penjumlahan dari keseluruhan skor untuk masing - masing indikator aspek keuangan, aspek operasional, dan aspek administratif. Dikarenakan cakupan penelitian terbatas hanya kepada aspek keuangan saja, maka jumlah hasil skor akan dihitung secara proporsional dengan porsi $35 \%$ atau total skor aspek keuangan sebesar 35 dari total skor keseluruhan sebesar 100. Dengan demikian setelah melakukan penghitungan total skor, maka tingkat kesehatan dari setiap perusahaan dapat ditentukan apakah perusahaan dimaksud memiliki kriteria sehat atau kurang sehat atau tidak sehat

\section{Rumus Penghitungan Indikator Tingkat Kesehatan BUMN Perasuransian dan Jasa Penjaminan untuk Aspek Keuangan}

Ada 4 rasio keuangan yang sudah ditetapkan berdasarkan PER-10/MBU/2014 yang digunakan untuk menghitung skor dari tingkat kesehatan BUMN Perasuransian dan Jasa Penjaminan ditinjau dari Aspek Keuangan, yaitu (1) Return on Equity, (2)Return on Asets,(3) Likuiditas, dan (4) Risk Based Capital.Untuk menghasilkan angka dari setiap rasio aspek keuangan di atas, di bawah disajikan rumus penghitungannya:

1. Rentabilitas 
a. Return on Equity (ROE)

$$
\text { ROE }=\frac{\text { Laba Sebelum Pajak }}{\text { Rata-rata Ekuitas }}
$$

b. Return on Asets (ROA)

$$
R O A=\frac{\text { Laba Setelah Pajak }}{\text { Rata-rata Aset }}
$$

2. Likuiditas

$$
\text { Likuiditas }=\frac{\text { Aset Lancar }}{\text { Hutang Lancar }}
$$

3. Solvabilitas

$$
\text { Solvabilitas }=\frac{\text { Total Aset }}{\text { Total Kewajiban }}
$$

4. Risk Based Capital (RBC)

$$
R B C=\frac{\text { Jumlah Tingkat Solvabilitas }}{\text { Jlh Batas Tk Solvabilitas Minimum }}
$$

Untuk mendapatkan hasil perhitungan dari rentabilitas, likuiditas, dan solvabilitas, maka data - data mengenai Laba Sebelum Pajak, Rata - rata Total Aset, Laba Setelah Pajak, Rata - rata Ekuitas, Aset Lancar, Hutang Lancar, Total Aset, dan Total Kewajiban terlebih dahulu diperoleh dari laporan keuangan masing - masing tahun berjalan. Sementara untuk menghitung risk based capital dilakukan dengan menghitung terlebih dahulu tingkat solvabilitas kemudian dibagikan terhadap Jumlah Batas Tingkat Solvabilitas Minimum. Angka yang ditetapkan untuk Jumlah Batas Tingkat Solvabilitas Minimum adalah angka yang ditetapkan oleh Pemerintah RI melalui Otoritas Jasa Keuangan berdasarkan POJK No. 71/POJK.05/2016 tentang Kesehatan Keuangan Perusahaan Asuransi dan Perusahaan Reasuransi. Dalam Peraturan OJK ini ditetapkan bahwa Risk Based Capital atau RBC minimum berdasarkan POJK No. 71/POJK.05/2016, adalah 120 persen. Ini berarti besarnya nilai aset bebas atau aset yang tersisa setelah perusahaan asuransi memenuhi kewajibannya minimal adalah 120 persen dari nilai risiko yang dihadapinya. Semakin tinggi $\mathrm{RBC}$ sebuah perusahaan asuransi, maka bisa dikatakan bahwa perusahaan asuransi tersebut semakin baik dan sehat.

\section{Analisis Laporan Keuangan}

Sehubungan dengan rasio - rasio yang digunakan untuk melakukan penilaian Kesehatan perusahaan BUMN di atas, analisis laporan keuangan dapat digunakan untuk melakukan penilaian terhadap kinerja maupun posisi keuangan yang dimiliki perusahaan. Analisis ini digunakan untuk dapat melihat bagaimana sesungguhnya keberhasilan perusahaan sekaligus juga untuk melihat bagaimana sebenarnya kemampuan perusahaan dalam menjalankan operasionalnya. Berikut beberapa analisis laporan keuangan sehubungan dengan penilaian kesehatan perusahaan.

\section{Rentabilitas}

Perusahaan yang mempunyai tujuan mendapatkan keuntungan akan selalu berusaha untuk meningkatkan jumlah laba yang akan diperoleh, namun laba yang besar belum tentu merupakan ukuran bahwa perusahaan telah bekerja secara efisien. Efisien atau tidaknya suatu perusahaan baru dapat diketahui dengan membandingkan antara laba yang diperoleh dengan modal atau asetyang digunakan untuk mendapatkan laba tersebut atau dengan kata lain dengan cara menghitung rasio rentabilitasnya.Menurut (Riyanto, 2014:35), rentabilitas suatu perusahaan menunjukkan perbandingan antara laba dengan aktiva atau modal yang menghasilkan laba tersebut. Sedangkan menurut (Hanafi, Mamduh M. dan Halim, 2014) 
mendefinisikan rentabilitas adalah rasio yang mengukur kemampuan perusahaan menghasilkan keuntungan pada tingkat penjualan, aset, dan modal saham tertentu"

a. Return On Equity (ROE)

ROE merupakan rasio yang digunakan untuk megukur sejauh mana perusahaan dalam melakukan aktivitasnya menghasilkan laba atau keuntungan dari kepemilikan ekuitas yang dimiliki. Menurut (Hanafi, Mamduh M. dan Halim, 2014), Return on Equity (ROE) merupakan rasio yang mengukur kemampuan perusahaan menghasilkan laba berdasarkan modal tertentu. Rasio ini merupakan ukuran profitabilitas dari sudut pandang pemegang saham. Dalam penilaian kesehatan perusahaan BUMN Perasuransian, rasio yang digunakan adalah perbandingan antara laba bersih sebelum pajak dibandingkan dengan total ekuitas yang dimiliki. Dengan demikian dapat dikatakan bahwa semakin tinggi tingkat ROE berarti dapat dikatakan bahwa perusahaan tersebut semakin baik dalam menghasilkan laba bersih.

b. Return on Assets (ROA)

ROA merupakan rasio yang digunakan untuk mengukur sejauh mana seluruh aset yang dimiliki perusahaan mampu menghasilkan laba. Menurut (Sutrisno, 2013), Return on Aset merupakan rasio yang mengukur kemampuan perusahaan menghasilkan laba bersih berdasarkan tingkat aset tertentu. Rasio ini juga sering disebut sebagai ROI (Return on Investment). Dalam penilaian kesehatan perusahaan BUMN Perasuransian, rasio yang digunakan adalah perbandingan antara laba bersih sesudah pajak dibandingkan dengan total aset yang dimiliki. Rasio yang tinggi menunjukkan efisiensi manajemen aset, yang berarti efisiensi manajemen. Dengan demikian dapat dikatakan bahwa semakin tinggi tingkat ROA berarti semakin baik perusahan dalam menghasilkan laba bersih.

2. Likuiditas

Pada prinsipnya, rasio likuiditas menggambarkan kemampuan perusahaan untuk menyelesaikan kewajiban jangka pendeknya. Menurut (Munawir, 2010), likuiditas adalah menunjukan kemampuan suatu perusahaan untuk memenuhi kewajiban keuangannya yang harus segera dipenuhi, atau kemampuan perusahaan untuk memenuhi kewajiban keuangan pada saat ditagih. Rasio yang digunakan dalam penilaian kesehatan perusahaan asuransi adalah rasio lancar yaitu perbandingan antara aset lancar dengan hutang lancar. Pada prinsipnya rasio lancar dikatakan baik apabila lebih dari $100 \%$ yang menyatakan bahwa asetlancar yang dimiliki oleh perusahaan masih sanggup untuk menutupi kewajiban lancar. Namun perlu diperhatikan bahwa rasio asetlancar yang terlalu tinggi bukan berarti dikatakan semakin baik mengingat terlalu besar asset lancar yang tidak produktif berarti semakin tidak efisien

\section{Solvabilitas}

Solvabilitas atau biasa disebut leverage dapat dikatakan merupakan kemampuan perusahaan dalam membiayai aset yang dimiliki dengan menggunakan pinjaman. Pengertian solvabilitas menurut (Kasmir, 2014), Rasio solvabilitas adalah rasio untuk mengukur kemampuan perusahaan memenuhi kewajiban - kewajiban jangka panjangnya. Sama halnya dengan likuiditas, apabila posisi tingkat solvabilitas berada di bawah angka satu atau 100\%, dapat dikatakan bahwa perusahaan dimaksud adalah insolvency atau tidak mampu melunasi seluruh kewajibannya meskipun seluruh aset yang dimiliki dilikuidasi untuk melunasi keseluruhan kewajiban - kewajibannya. Berbeda dengan likuiditas bahwa semakin tinggi tingkat solvabilitas berarti perusahaan semakin aman atau semakin mudah untuk melunasi kewajiban - kewajibannya.

\section{Risk Based Capital (RBC)}

RBC adalah metode perhitungan kesehatan perusahaan asuransi yang diwajibkan oleh Otoritas Jasa Keuangan (OJK). Secara sederhana, RBC adalah rasio modal perusahaan asuransi dibandingkan dengan nilai risiko yang dihadapinya. Rasio minimal yang diwajibkan OJK adalah $120 \%$, artinya perusahaan asuransi harus memiliki aset bebas (aset yang tersisa setelah memenuhi kewajibannya) minimal sebesar $120 \%$ dari nilai risiko yang dihadapinya 


\section{METODA PENELITIAN}

Jenis penelitian yang digunakan dalam penelitian ini adalah penelitian studi kasus dengan pendekatan kuantitatif. Fokus penleitian ini adalah untuk melakukan analisis penilaian tingkat kesehatan dari PT. Asuransi Jiwasraya (Persero) dimana pada tahun 2020 mengalami gagal bayar. Pada penelitian ini ada tiga tahap yang digunakan untuk menganalisis data yaitu:

1. Tahap pertama, yaitu menghitung serta menentukan skor penilaian dari masing-masing indikator untuk aspek keuangan. Indikator yang digunakan adalah Peraturan Menteri BUMN No: PER-10/MBU/2014 dengan menggunakan rumus penghitungan indikator tingkat kesehatan BUMN Perasuransian dan Jasa Penjaminan yang ditinjau dari sisi aspek keuangan. Indikator yang dimaksud adalah:

a. Rentabilitas, yang terdiri dari: Return on Aset (ROA) dan Return on Equity (ROE).

b. Likuiditas

c. Solvabilitas

d. Risk Based Capital (RBC)

2. Tahap kedua, yaitu melakukan analisis laporan keuangan berdasarkan rasio - rasio ROE, ROA, Likuiditas, Solvabilitas dan RBC.

3. Tahap ketiga, yaitu menghitung nilai dari setiap indikator di atas untuk setiap tahunnya sekaligus memberikan penilaian dengan kriteria Sangat Baik, Baik, Cukup, Kurang, ataupun Sangat Kurang sesuai dengan kriteria yang ditetapkan pada Permen Nomor PER10/MBU/2014 seperti yang disajikan dala Tabel 2 di atas.

4. Tahap keempat, yaitu menentukan tingkat kesehatan BUMN ditinjau dari aspek keuangan. Dikarenakan total bobot aspek keuangan adalah sebesar 35 dari total bobot 100, maka bobot untuk menentukan tingkat kesehatan ditinjau dari aspek keuangan dilakukan dengan menghitung secara proporsional sehingga boobotnya menjadi 35/100 atau 35\%, kemudian dikalikan dengan Penilaian Tingkat Kesehatan yang ditetapkan oleh Keputusan Menteri BUMN berdasarkan KEP-100/MBU/2020 sehingga tingkat kesehatan BUMN Jasa Keuangan Bidang Perasuransian ditinjau dari aspek keuangan adalah sebagai berikut:

\begin{tabular}{|c|c|c|c|}
\hline & KRITERIA & TOTAL SKOR (TS) & $\begin{array}{c}\text { ASPEK KESEHATAN } \\
(35 \% \times \text { TS })\end{array}$ \\
\hline \multirow[t]{4}{*}{ a } & Sehat & & \\
\hline & AAA & $>95$ & $>33,25$ \\
\hline & AA & $80<\mathrm{TS} \leq 95$ & $28<\mathrm{TS} \leq 33,25$ \\
\hline & A & $65<\mathrm{TS} \leq 80$ & $22,75<\mathrm{TS} \leq 28$ \\
\hline \multirow[t]{4}{*}{ b } & Kurang Sehat & & \\
\hline & BBB & $50<\mathrm{TS} \leq 65$ & $17,5<\mathrm{TS} \leq 22,75$ \\
\hline & BB & $40<\mathrm{TS} \leq 50$ & $14<\mathrm{TS} \leq 17,5$ \\
\hline & B & $30<\mathrm{TS} \leq 40$ & $10,5<\mathrm{TS} \leq 14$ \\
\hline \multirow[t]{4}{*}{ c } & Tidak Sehat & & \\
\hline & $\mathrm{CCC}$ & $20<\mathrm{TS} \leq 30$ & $7<\mathrm{TS} \leq 10,5$ \\
\hline & $\mathrm{CC}$ & $10<\mathrm{TS} \leq 20$ & $3,5<\mathrm{TS} \leq 7$ \\
\hline & $\mathrm{C}$ & $\mathrm{TS} \leq 10$ & $\mathrm{TS} \leq 5$ \\
\hline
\end{tabular}

Dengan menjumlahkan total skor dari rentabilitas, likuiditas, danrisk based capitaldan melakukan penilaian secara proporsional berdasarkan penggolongan penilaian tingkat kesehatan di atas, maka tingkat kesehatan dari PT. Asuransi Jiwasraya (Persero) dapat ditetapkan berdasarkan kriteria yang tersaji pada Tabel 4 di atas.

\section{ANALISIS DAN PEMBAHASAN}

1. Penghitungan Rasio Keuangan dan Analisis Laporan Keuangan 


\section{a. Rentabilitas}

Dari penelusuran laporan keuangan yang dipublikasikan oleh PT Asuransi Jiwasraya (Persero) menunjukkan bahwa PT. Jiwasraya tidak dapat menunjukkan laporan keuangan untuk tahun 2017 baik laporan keuangan yang diaudit oleh kantor akuntan publik maupun laporan keuangan internal. Dengan demikian, penulis tidak dapat menghitung rasio rentabilitas untuk tahun 2017.

Dengan tidak dipublikasikannya laporan keuangan untuk tahun 2017 dapat dikatakan bahwa ada sesuatu permasalahan besar dalam hal pertanggungjawaban keuangan PT. Asuransi Jiwasraya. Dari hasil perhitungan penulis bahwa PT. Asuransi Jiwasraya mengalami kerugian besar di tahun 2017. Hal ini terbukti dengan merosotnya saldo ekuitas di tahun 2016 sebesar plus Rp 5.441.432.000.000,- menjadi minus Rp 30.263.509.000.000,(lihat Tabel 5). Hal ini berarti ada kerugian sebesar Rp 35.704.941.000.000,- selama dua tahun berjalan. Kalau rugi bersih setelah pajak selama tahun 2018 adalah sebesar minus Rp 19.739.382.000.000,- (lihat Tabel 6 di bawah) berarti PT. Jiwasraya mengalami kerugian sebesar Rp 15.965.559.000.000,- selama tahun 2017 atau rugi sebesar 15.97 triliun rupiah.

Tabel 5 dan Tabel 6 di bawah menunjukkan hasil penghitungan Return on Equity (ROE) dan Return on Assets (ROA) berdasarkan data Laporan keuangan yang dipubikasikan oleh PT. Asuransi Jiwasraya

\begin{tabular}{lccccr}
\multicolumn{7}{c}{ Tabel 5. Hasil Penghitungan Return on Equity (ROE) } \\
\hline Uraian & $\mathbf{2 0 1 5}$ & $\mathbf{2 0 1 6}$ & $\mathbf{2 0 1 8}$ & $\mathbf{2 0 1 9}$ & $\mathbf{2 0 2 0}$ \\
\hline Laba Bersih Sebelum Pajak (Rp juta) & $1,102,313$ & $1,694,609$ & $(19,670,444)$ & $(4,112,717)$ & $(4,046,333)$ \\
Total Ekuitas Tahun Sebelumnya (Rp juta) & $2,374,224$ & $3,361,583$ & $5,441,432$ & $(30,263,509)$ & $(34,566,950)$ \\
Total Ekuitas Tahun Berjalan (Rp juta) & $3,361,583$ & $5,441,432$ & $(30,263,509)$ & $(34,566,950)$ & $(38,636,502)$ \\
Rata-rata Total Ekuitas (Rp juta) & $2,867,903$ & $4,401,507$ & $(12,411,039)$ & $(32,415,230)$ & $(36,601,726)$ \\
\multicolumn{1}{c}{ ROE } & $\mathbf{3 8 . 4 4 \%}$ & $\mathbf{3 8 . 5 0 \%}$ & $\mathbf{1 5 8 . 4 9 \%}$ & $\mathbf{1 2 . 6 9 \%}$ & $\mathbf{1 1 . 0 6 \%}$ \\
\hline Sumber : Data diolah & & & & &
\end{tabular}

Dari Tabel 5 di atas, terlihat bahwa PT. Jiwasraya sejak tahun 2018 sudah mengalami Rugi Bersih Sebelum Pajak masing-masing Rp 19,67 triliun di tahun 2018, Rp 4,14 triliun di tahun 2019 dan Rp 4,04 triliun di tahun 2020. Dan dari hasil penghitungan penulis menunjukkan di tahun 2017 juga PT. Asuransi Jiwasraya sudah mengalami kerugian. Hal ini berarti PT. Jiwasraya sudah mengalami permasalahan keuangan sejak tahun 2017.

Di samping itu, apabila dilihat dari saldo ekuitas yang menunjukkan minus Rp 30,26 triliun di tahun 2018, minus Rp 34,57 triliun di tahun 2019, dan minus Rp 38,64 triliun di tahun 2020 dan dengan menggunakan rumus akuntansi dimana Total Aset $=$ Total Kewajiban + Total Ekuitas, secara matematis apabila total ekuitas bersaldo negative, maka total aset lebih kecil dibandingkan total kewajiban sebesar angka - angka di atas untuk masing - masing tahun di atas. Dengan demikian dapat dikatakan bahwa PT. Asuransi Jiwasraya sudah tidak mampu lagi membayar seluruh kewajibannya walaupun dengan menjual seluruh aset yang dimiliki.

Apabila melihat dari hasil penghitungan ROE pada Tabel 5 di atas yang menunjukkan angka positif, hal ini bukan menunjukkan kinerja yang positif dikarenakan Laba Bersih Sebelum Pajak yang dihasilkan adalah sesungguhnya negatif. Hasil perhitungan ROE yang menunjukkan hasil positif dikarenakan pembagi (total ekuitas) adalah sudah bersaldo negatif sehingga sesungguhnya tingkat imbal hasil (return) dibandingkan dengan total ekuitas berkinerja negative

Tabel 6 di bawah menunjukkan hasil penghitungan Return on Assets (ROA) yang juga bersumber dari data Laporan keuangan yang dipubikasikan oleh PT. Asuransi Jiwasraya 
Tabel 6. Hasil Penghitungan Return on Assets (ROA)

\begin{tabular}{llcccc}
\hline \multicolumn{1}{c}{ Uraian } & $\mathbf{2 0 1 5}$ & $\mathbf{2 0 1 6}$ & $\mathbf{2 0 1 8}$ & $\mathbf{2 0 1 9}$ & $\mathbf{2 0 2 0}$ \\
\hline Laba Bersih Setelah Pajak (Rp juta) & $1,066,408$ & $1,706,323$ & $(19,739,382)$ & $(4,140,445)$ & $(4,046,500)$ \\
Total Aset Tahun Sebelumnya (Rp juta) & $20,753,870$ & $25,571,012$ & $38,635,059$ & $23,046,407$ & $18,151,030$ \\
Total Aset Tahun Berjalan (Rp juta) & $25,571,012$ & $38,635,059$ & $23,046,407$ & $18,151,030$ & $15,726,246$ \\
Rata-rata Total Aset (Rp juta) & $23,162,441$ & $32,103,035$ & $30,840,733$ & $20,598,719$ & $16,938,638$ \\
\multicolumn{1}{c}{ ROA } & $\mathbf{4 . 6 0 \%}$ & $\mathbf{5 . 3 2 \%}$ & $\mathbf{- 6 4 . 0 0 \%}$ & $\mathbf{- 2 0 . 1 0 \%}$ & $\mathbf{- 2 3 . 8 9 \%}$ \\
\hline
\end{tabular}

Sumber : Data diolah

Dari Tabel 6 di atas terlihat bahwa Laba Bersih Setelah pajak memperlihatkan rugi sebesar Rp 19,74 triliun di tahun 2018, rugi Rp 4,14 triliun di tahun 2019, dan rugi $\mathrm{Rp} \mathrm{4,07}$ triliun di tahun 2020. Hal ini berarti bahwa PT Asuransi Jiwasraya (Persero) mengalami rugi bersih sejak tahun 2017. Hal ini dapat dilihat dari hasil penghitungan penulis menunjukkan di tahun 2017 juga PT. Asuransi Jiwasraya sudah mengalami rugi bersih sebesar Rp 15,97 triliun. Dengan demikian dapat dikatakan bahwa PT. Asuransi Jiwasraya sedang mengalami permasalah besar dengan mengalami rugi beruntun sejak tahun 2017.

Dilihat dari sisi total aset pada Tabel 6 di atas, PT. Asuransi Jiwasraya mulai mengalami penurunan saldo aset sejak tahun 2018. Hal ini kemungkinan dikarenakan menurunnya total asset lancar dimana PT Asuransi Jiwasraya (Persero) harus melunasi hutang - hutang jangka pendeknya khususnya klaim nasabah yang sudah jatuh tempo.

Dilihat dari rasio ROA, PT. Jiwasraya memperoleh hasil negatifatau minus $64 \%$ di tahun 2018, minus $20,1 \%$ di tahun 2019, dan minus $23,89 \%$ di tahun 2020 . Hal ini jelas menunjukkan bahwa imbal hasil perusahaan dari aset yang dimiliki adalah negatif atau mengalami kerugian. Apabila dianalisis lebih lanjut bahwa ROA di tahun 2018 menujukkan angka minus $64 \%$. Maka ini berarti PT. Asuransi Jiwasraya (Persero) mengalami kehilangan sebesar $64 \%$ dari asset yang dimiliki. Di tahun ini jelas bahwa perusahaan sudah mengalami kesulitan keuangan.

Dengan demikian dilihat dari sisi rentabilitas baik dari ROE maupun ROA bahwa PT. Asuransi Jiwasraya memperoleh hasil negatif atau mengalami kerugian dari modal atau aset yang dimilikinya. Dengan melakukan analisis laporan keuangan dari akun-akun maupun dari rasio rentabilitas di atas menunjukkan bahwa PT. Asuransi Jiwasraya sudah mengalami kesulitan keuangan

\section{b. Likuiditas}

Dari catatan atas laporan keuangan yang dipublikasikan oleh PT Asuransi Jiwasraya (Persero) sejak tahun 2015 hingga tahun 2020 kecuali tahun 2017, penulis tidak harus menghitung rasiolikuiditas dikarenakan PT Asuransi Jiwasraya (Persero) sudah menyajikan data - data mengenai likuiditas dalam laporan keuangan tahunannya, sebagai berikut:

\begin{tabular}{cc}
\multicolumn{2}{c}{ Tabel 7. Rasio Likuiditas } \\
\hline Tahun & Rasio \\
\hline 2015 & $374.78 \%$ \\
2016 & $156.00 \%$ \\
2018 & $29.47 \%$ \\
2019 & $5.67 \%$ \\
2020 & $4.20 \%$ \\
\hline Sumber : Data diolah &
\end{tabular}

Terlihat bahwa rasio likuiditas PT. Asuransi Jiwasraya dari tahun ke tahun mengalami penurunan dari 374,78\% di tahun 2015, 156\% di tahun 2016, 29,47 di tahun 2018, menjadi 5,67\% di tahun 2019, dan terakhir semakin menurun menjadi $4,20 \%$ di tahun 2020 . Dengan melihat definisi likuiditas yang menyatakan bahwa rasio likuiditas menggambarkan kemampuan perusahaan untuk menyelesaikan kewajiban jangka pendeknya dan dengan melihat tabel di atas, berarti kemampuan PT Asuransi Jiwasraya (Persero) dalam menyelesaikan kewajiban jangka pendeknya semakin mengecil. Dengan perkataan lain bahwa PT. Asuransi Jiwasraya sudah semakin kesulitan dalam hal keuangan khususnya dalam menyelesaikan kewajiban - kewajiban jangka pendeknya

c. Risk Based Capital 
Sama halnya dengan likuiditas, penulis tidak harus menghitung rasio Risk Based Capital (RBC) dikarenakan PT Asuransi Jiwasraya (Persero) sudah menyajikan data RBC pada catatan atas laporan keuangan. Data - data sejak tahun 2015 hingga tahun 2020 kecuali tahun 2017 diperoleh adalah sebagai berikut:

\begin{tabular}{cc}
\multicolumn{2}{c}{ Tabel 8. Rasio Risk Based Capital } \\
\hline Tahun & Rasio (\%) \\
\hline 2015 & 162.16 \\
2016 & 200.15 \\
2018 & $(1,431.02)$ \\
2019 & $(1,866.10)$ \\
2020 & $(23.89)$ \\
\hline
\end{tabular}

Angka yang ditetapkan oleh Pemerintah RI melalui Otoritas Jasa Keuangan berdasarkan POJK No. 71/POJK.05/2016 tentang Kesehatan Keuangan Perusahaan Asuransi dan Perusahaan Reasuransi untuk Jumlah Batas Tingkat Solvabilitas Minimumadalah 120 persen. Ini berarti besarnya nilai aset bebas atau aset yang tersisa setelah perusahaan asuransi memenuhi kewajibannya minimal adalah 120 persen dari nilai risiko yang dihadapinya. Dalam hal ini, RBC PT Asuransi Jiwasraya (Persero) sejak tahun 2018 sudah jauh di bawah standar yaitu mencapai minus $1.431,02 \%$ untuk tahun 2018 , minus $1.866,10 \%$ untuk tahun 2019 dan minus 23,89\% untuk tahun 2020. Dengan data di atas dapat dikatakan bahwa sejak tahun 2018 bahwa PT. Asuransi Jiwasraya sudah benar-benar tidak bisa memenuhi kewajiban minimal.

2. Kriteria Penilaian Bobot dari Masing-masing Aspek Keuangan

a. Return on Equity (ROE)

Dari Tabel 2 yang telah diuraikan di atas bahwa untuk menentukan kriteria dari masingmasing aspek keuangan adalah:

Tabel 2. Daftar Skor Aspek Keuangan PT. Asuransi Jiwasraya (Persero)

\begin{tabular}{|c|c|c|c|c|c|c|c|c|}
\hline \multicolumn{2}{|c|}{ 1. Return on Equity } & \multicolumn{2}{|c|}{ 2. Return on Assets } & \multicolumn{2}{|c|}{ 3. Likuiditas } & \multicolumn{2}{|c|}{ 4. Risk Based Capital } & \multirow{2}{*}{ Kriteria } \\
\hline ROE (\%) & Score & ROA (\%) & Score & $\%$ & Score & RBC (\%) & Score & \\
\hline $\mathrm{ROE} \geq \mathrm{x}+4$ & 7.5 & $\mathrm{ROA} \geq 5$ & 7.5 & $x \geq 150$ & 10 & $x \geq 150$ & 10 & Sangat Baik \\
\hline$x+4>\operatorname{ROE} \geq x+3$ & 6 & $5>\mathrm{ROA} \geq 4$ & 6 & $150>x \geq 130$ & 8 & $150>x \geq 130$ & 8 & Baik \\
\hline$x+3>\operatorname{ROE} \geq x+2$ & 4.5 & $4>\mathrm{ROA} \geq 3$ & 4.5 & $130>x \geq 120$ & 6 & $130>x \geq 120$ & 6 & Cukup \\
\hline$x+2>R O E \geq 0$ & 2 & $3>\mathrm{ROA} \geq 0$ & 2 & $120>x \geq 100$ & 3 & $120>x \geq 100$ & 3 & Kurang \\
\hline $\mathrm{ROE}<0$ & 0 & ROA $<0$ & 0 & $\mathrm{x}<100$ & 0 & $\mathrm{x}<100$ & 0 & Sangat Kurang \\
\hline
\end{tabular}

Catatan: $\mathrm{x}=\mathrm{BI}$ Rate

Sumber: Permen BUMN Nomor PER-10/MBU/2014

Dan dalam menentukan batasan penilaian kriteria untuk ROE, harus terlebih dahulu disesuaikan dengan BI Rate. BI Rate selama tahun 2015 hingga tahun 2020 adalah sbb:

\begin{tabular}{cc}
\multicolumn{2}{c}{ Tabel 9. BI Rate } \\
\hline Tahun & BI Rate \\
\hline 2015 & 7.50 \\
2016 & 4.75 \\
2018 & 6.00 \\
2019 & 5.00 \\
2020 & 3.75 \\
\hline Sumber : bps.go.id (Data diolah) &
\end{tabular}

Dengan demikian, daftar skor aspek ROE setelah disesuaikan dengan BI Rate adalah : Tabel 11a. Skor Aspek ROE

\begin{tabular}{cccc}
\hline Tahun & \% & Skor & Kriteria \\
\hline 2015 & 38.44 & 7.50 & Sangat Baik \\
2016 & 38.50 & 7.50 & Sangat Baik \\
2018 & 158.49 & 7.50 & Sangat Baik \\
2019 & 12.69 & 7.50 & Sangat Baik \\
2020 & 11.06 & 7.50 & Sangat Baik \\
\hline Sumber : Data diolah & & &
\end{tabular}


Dengan adanya Tabel 10 di atas, maka penentuan kriteria apakah tingkat ROE untuk masing-masing tahun sudah dapat dilakukan. Hasil penentuan kriteria dimaksud adalah :

Tabel 11a. Skor Aspek ROE

\begin{tabular}{cccc}
\hline Tahun & \% & Skor & Krite ria \\
\hline 2015 & 38.44 & 7.50 & Sangat Baik \\
2016 & 38.50 & 7.50 & Sangat Baik \\
2018 & 158.49 & 7.50 & Sangat Baik \\
2019 & 12.69 & 7.50 & Sangat Baik \\
2020 & 11.06 & 7.50 & Sangat Baik \\
\hline Sumber : Data diolah & &
\end{tabular}

Angka 7,5 di tahun 2015 diperoleh dari perhitungan ROE sebesar 38,44\% dan angka ini berada di posisi $\mathrm{ROE} \geq 11,5$ sehingga memperoleh skor 7,5. Demikian juga di tahun 2016, angka 7,5 diperoleh dari posisi $\mathrm{ROE}=38,50 \%$ dan berada di posisi $\mathrm{ROE} \geq 8,75$ sehingga memperoleh skor 7,5. Dari hasil perhitungan di atas terlihat bahwa ROE untuk tahun 2018 sampai dengan 2020 adalah positif, namun sesungguhnya PT. Asuransi Jiwasraya (Persero) mengalami laba minus atau mengalami kerugian untuk tahun 2018 hingga tahun 2020. Angka positif ini terjadi dikarenakan laba minus dan pembaginya saldo ekuitas juga minus sehingga rasio ROE menjadi positif. Hal ini kurang tepat kalau dikatakan bahwa kriteria penilaian untuk tahun 2018 hingga tahun 2020 adalah sangat baik. Oleh karenanya, penulis mengatakan bahwa sesungguhnya PT. Asuransi Jiwasraya (Persero) memperoleh rasio ROE negatif yang berarti returnnegatif atau dalam hal ini penulis memberikan angka nol sehingga dengan demikian penulis menyajikan hasil penghitungan ulang sebagai berikut:

Tabel 11b. Skor Aspek ROE

\begin{tabular}{cccc}
\hline Tahun & \% & Skor & Kriteria \\
\hline 2015 & 38.44 & 7.50 & Sangat Baik \\
2016 & 38.50 & 7.50 & Sangat Baik \\
2018 & 0.00 & 0.00 & Sangat Kurang \\
2019 & 0.00 & 0.00 & Sangat Kurang \\
2020 & 0.00 & 0.00 & Sangat Kurang \\
\hline
\end{tabular}

Sumber : Data diolah

Dari Tabel 11b di atas dapat dikatakan bahwa untuk tahun 2018 hingga 2020 kriteria penilaian untuk PT. Asuransi Jiwasraya (Persero) adalah "Sangat Kurang". Kriteria penilaian sesungguhnya mungkin akan sejalan dengan penilaian kriteria untuk ROA

b. Return on Assets (ROA)

Dari Tabel 2 yang telah diuraikan di atas bahwa untuk menentukan kriteria dari aspek ROA adalah minimal 5\% untuk mendapatkan kriteria "Sangat Baik", 5\%> ROA $\geq 4 \%$ untuk mendapatkan kriteria "Baik", 4\%> ROA $\geq 3 \%$ untuk mendapatkan kriteria "Cukup", 3\%> $\mathrm{ROA} \geq 4 \%$ untuk mendapatkan kriteria "Kurang" dan ROA $<0$ untuk kriteria "Sangat Kurang". Dengan cara yang sama seperti penentuan skor ROE, hasil penentuan kriteria ROA untuk tahun 2015 hingga tahun 2020 adalah sebagai berikut :

Tabel 12. Skor Aspek ROA

\begin{tabular}{cccc}
\hline Tahun & \% & Skor & Kriteria \\
\hline 2015 & $4.60 \%$ & 6.00 & Baik \\
2016 & $5.32 \%$ & 7.50 & Sangat Baik \\
2018 & $-64.00 \%$ & 0.00 & Sangat Kurang \\
2019 & $-20.10 \%$ & 0.00 & Sangat Kurang \\
2020 & $-23.89 \%$ & 0.00 & Sangat Kurang \\
\hline Sumber : Data diolah & &
\end{tabular}

Berbeda dengan tabel penilaian kiriteria ROE, dari tabel di atas jelas terlihat bahwa kriteria penilaian ROA menunjukkan bahwa sejak tahun 2018 PT Asuransi Jiwasraya (Persero) memang benar - benar sudah mengalami kesulitan keuangan dengan kriteria "Sangat 
Kurang" dimana kemampuan perusahaan untuk menghasilkan laba dengan menggunakan seluruh asset yang dimiliki adalah memang benar - benar jauh dari yang diharapkan

c. Likuiditas

Dari Tabel 2 yang telah diuraikan di atas bahwa untuk menentukan kriteria dari aspek likuiditas adalah minimal 150\%untuk mendapatkan kriteria "Sangat Baik", 150\% > \% Likuiditas $\geq 130 \%$ untuk mendapatkan kriteria "Baik", $130 \%>\%$ Likuiditas $\geq 120 \%$ untuk mendapatkan kriteria "Cukup", $120 \%>\%$ Likuiditas $\geq 100 \%$ untuk mendapatkan kriteria "Kurang" dan \% Likuiditas < 0 untuk kriteria "Sangat Kurang". Hasil penentuan kriteria Likuiditas untuk tahun 2015 hingga tahun 2020 adalah sebagai berikut:

\section{Tabel 13. Skor Aspek Likuiditas}

\begin{tabular}{cccc}
\hline Tahun & $\%$ & Skor & Kriteria \\
\hline 2015 & $374.78 \%$ & 10.00 & Sangat Baik \\
2016 & $156.00 \%$ & 10.00 & Sangat Baik \\
2018 & $29.47 \%$ & 0.00 & Sangat Kurang \\
2019 & $5.67 \%$ & 0.00 & Sangat Kurang \\
2020 & $4.20 \%$ & 0.00 & Sangat Kurang \\
\hline \multicolumn{2}{l}{ Sumber : Data diolah }
\end{tabular}

Berdasarkan hasil penghitungan yang tersaji pada Tabel 13 di atas jelas terlihat bahwa kriteria penilaian Likuiditas menunjukkan bahwa sejak tahun 2018 PT Asuransi Jiwasraya (Persero) memang sudah benar - benar mengalami kesulitan likuiditas dengan kriteria "Sangat Kurang" dimana perusahaan sudah benar - benar tidak mampu lagi untuk membayar hutang - hutang jangka pendeknya dengan menggunakan aset lancar yang dimilikinya

\section{d. Risk Based Capital (RBC)}

Dari Tabel 2 yang telah diuraikan di atas bahwa untuk menentukan kriteria dari aspek Risk Based Capital (RBC) adalah minimal 150\% untuk mendapatkan kriteria "Sangat Baik", $150 \%>\mathrm{RBC} \geq 130 \%$ untuk mendapatkan kriteria "Baik", $130 \%>\mathrm{RBC} \geq 120 \%$ untuk mendapatkan kriteria "Cukup", 120\% > RBC $\geq 100 \%$ untuk mendapatkan kriteria "Kurang" dan RBC $<0$ untuk kriteria "Sangat Kurang". Hasil penentuan kriteria Likuiditas untuk tahun 2015 hingga tahun 2020 adalah sebagai berikut:

Tabel 14. Skor Aspek Risk Based Capital

\begin{tabular}{cccc}
\hline Tahun & $\%$ & Skor & Kriteria \\
\hline 2015 & $162.16 \%$ & 10.00 & Sangat Baik \\
2016 & $200.15 \%$ & 10.00 & Sangat Baik \\
2018 & $-1431.02 \%$ & 0.00 & Sangat Kurang \\
2019 & $-1866.10 \%$ & 0.00 & Sangat Kurang \\
2020 & $-23.89 \%$ & 0.00 & Sangat Kurang \\
\hline
\end{tabular}

Sumber : Data diolah

Berdasarkan hasil penghitungan yang tersaji pada Tabel 13 di atas jelas terlihat bahwa kriteria penilaian RBC menunjukkan bahwa sejak tahun 2018 PT Asuransi Jiwasraya (Persero) memang rasio modal PT. Asuransi Jiwasraya benar - benar sudah tidak memenuhi standar yang ditetapkan bila dibandingkan dengan nilai risiko yang dihadapinya dengan kriteria penilaian "Sangat Kurang".

3. Tingkat Kesehatan

Dengan menjumlahkan total skor dari rentabilitas, likuiditas, dan risk based capital dan melakukan penilaian secara proporsional berdasarkan penggolongan penilaian tingkat kesehatan di atas, dan berdasarkan kriteria yang tersaji pada Tabel 4 di atas, maka tingkat kesehatan dari PT. Asuransi Jiwasraya (Persero) diperoleh hasil penghitungan pada Tabel 15 berikut: 
Tabel 15. Total Skor Aspek Keuangan

\begin{tabular}{cccccccc}
\hline Tahun & \multirow{2}{*}{ ROE } & \multirow{2}{*}{ ROA } & Likuiditas & RBC & $\begin{array}{c}\text { Total Skor } \\
\text { (TS) }\end{array}$ & $\begin{array}{c}\text { Rentang } \\
\text { Skor }\end{array}$ & Kriteria \\
\hline 2015 & 7.50 & 6.00 & 10.00 & 10.00 & 33.50 & $>33,25$ & Sehat - AAA \\
2016 & 7.50 & 7.50 & 10.00 & 10.00 & 35.00 & $>33,25$ & Sehat - AAA \\
2018 & 0.00 & 0.00 & 0.00 & 0.00 & 0.00 & TS $<5$ & Tidak Sehat - C \\
2019 & 0.00 & 0.00 & 0.00 & 0.00 & 0.00 & TS $<5$ & Tidak Sehat - C \\
2020 & 0.00 & 0.00 & 0.00 & 0.00 & 0.00 & TS $<5$ & Tidak Sehat - C \\
\hline
\end{tabular}

Sumber : Data diolah

Dari hasil penghitungan di atas terlihat bahwa tahun 2015 dan 2016, PT. Asuransi Jiwasraya (Persero) masih dalam posisi Sehat dengan kualifikasi AAA. Namun sejak tahun 2018 PT. Asuransi Jiwasraya (Persero) sudah dinyatakan "Tidak Sehat" bahkan dengan kualifikasi paling rendah yaitu C. Dengan demikian dapat dikatakan bahwa PT. Asuransi Jiwasraya (Persero) sebenarnya sudah tidak sanggup lagi menyelesaikan seluruh kewajibannya sejak tahun 2018 dalam hal pembayaran klaim oleh nasabah dikarenakan kemampuan PT. Asuransi Jiwasraya (Persero) sudah tidak memungkinkan lagi bila ditinjau dari posisi keuangan. Dan dari sini dapat dikatakan bahwa "Gagal Bayar" dari PT. Asuransi Jiwasraya (Persero) di tahun 2020 dikarenakan posisi keuangan yang tidak memungkinkan lagi untuk membayar klaim nasabah

\section{SIMPULAN, KETERBATASAN DAN SARAN}

A. Kesimpulan

Berdasarkan penelitian dan hasil analisis yang telah dilakukan, maka peneliti dapat menyimpulkan hal-hal sebagai berikut:

1. Dari hasil analisis laporan keuangan berdasarkan data-data laporan keuangan dan perhitungan ROE, ROA, likuiditas, dan RBC terlihat bahwa PT. Asuransi Jiwasraya (Persero) telah mengalami permasalahan keuangan sejak tahun 2018. Permasalahan keuangan inilah yang menyebabkan terjadinya "Gagal Bayar" terhadap klaim yang diajukan oleh nasabah di tahun 2020.

2. Hasil penilaian skor untuk aspek ROA, likuiditas, dan RBC menunjukkan bahwa sejak tahun 2018, status keuangan PT. Asuransi Jiwasraya (Persero) berada pada posisi sangat tidak baik atau berada pada kriteria "Sangat Kurang".

3. Hasil penilaian tingkat kesehatan menunjukkan bahwa sejak tahun 2018, PT. Asuransi Jiwasraya (Persero) sudah berada pada posisi "Tidak Sehat dengan predikat C". Predikat ini menunjukkan bahwa posisi keuangan PT. Asuransi Jiwasraya (Persero) sudah tidak memungkikan lagi menyelesaikan klaim pembayaran kepada nasabah.

B. Saran-saran

1. Pemerintah RI harus lebih ketat lagi dalam hal mengawasi pertanggungjawaban keuangan dari semua perusahaan asuransi apalagi dalam hal ini PT Asuransi Jiwasraya (Persero) berstatus BUMN yang notabene mengumpulkan uang dari masyarakat sampai merugikan masyarakat banyak dikarenakan PT Asuransi Jiwasraya (Persero) tidak sanggup membayar klaim nasabah.

2. PT Asuransi Jiwasraya (Persero) sebagai perusahaan yang mengumpulkan dana dari banyak masyarakat seharusnya lebih terbuka kepada masyarakat umum dalam penyajian dan publikasi laporan keuangan mengingat tahun 2017 perusahaan tidak mempublikasikan laporan keuangannya.

3. PT Asuransi Jiwasraya (Persero) harus mampu menyelesaikan permasalahan gagal bayar dan mengembalikan dana masyarakat yang sudah dikumpulkannya sekaligus 
juga harus mampu menjadikan PT Asuransi Jiwasraya (Persero) menjadi perusahaan yang sehat, terbuka, serta dikelola secara profesional.

4. Penelitian ini sebaiknya ditindaklanjuti dengan melakukan penelitian lengkap dengan melakukan penilaian kesehatan perusahaan tidak hanya dari aspek keuangan saja tetapi juga dari aspek operasional dan administrasi sehingga diperoleh penghitungan yang lengkap dan tentunya diharapkan dapat memberikan interpretasi yang lengkap juga

\section{DAFTAR PUSTAKA}

Badan Pusat Statistik. (2021). diakses pada tanggal 1 Juni 2021 dari http://www.bps.go.id Bahara, Wicak Lingga, dkk. (2015). Analisis Tingkat Kesehatan Perusahaan dari Aspek Keuangan Berdasarkan Surat Keputusan Menteri BUMN Nomor: KEP100/MBU/2002 (Studi Kasus pada PT ADHI KARYA (Persero) Tbk. Periode 2012-2014)

Hanafi, Mamduh M. dan Halim, A. (2014). Analisis Laporan Keuangan (Edisi Ketu). Yogyakarta: UPP AMP YKPN.

Kasmir. (2014). Analisis Laporan Keuangan, Edisi Satu, Cetakan Ketujuh. Raja Grafindo Persada, V(2015), 115.

Munawir. (2010). Analisa Laporan Keuangan. Edisi keempat. Cetakan kelima belas. In Yogyakarta.

Riyanto, B. (2014). Dasar - Dasar Pembelanjaan Perusahaan (Edisi Keem). Yogyakarta: BPFE. Sutrisno. (2013). Manajemen Keuangan Teori Konsep dan Aplikasi. In Manajemen Keuangan Teori Konsep dan Aplikasi (p. 229).

Undang-undang no 19. (2003). UNDANG-UNDANG REPUBLIK INDONESIA NOMOR 19 TAHUN 2003 TENTANG BADAN USAHA MILIK NEGARA. Undang-Undang Republik Indonesia Nomor 20 Tahun 2003 Tentang Badan Usaha Milik Negara, 14(1), 1-26. 